\title{
Barbara Bohac, La dernière mode de Mallarmé sous les feux du drame solaire
}

\section{Ida Merello}

\section{Q OpenEdition}

1 Journals

\section{Edizione digitale}

URL: http://journals.openedition.org/studifrancesi/9314

DOI: 10.4000/studifrancesi.9314

ISSN: 2421-5856

\section{Editore}

Rosenberg \& Sellier

\section{Edizione cartacea}

Data di pubblicazione: 1 juin 2008

Paginazione: 217

ISSN: 0039-2944

\section{Notizia bibliografica digitale}

Ida Merello, «Barbara Bohac, La dernière mode de Mallarmé sous les feux du drame solaire», Studi

Francesi [Online], 154 (LII | I) | 2008, online dal 30 novembre 2015, consultato il 13 janvier 2021. URL: http://journals.openedition.org/studifrancesi/9314 ; DOI: https://doi.org/10.4000/studifrancesi.9314

Questo documento è stato generato automaticamente il 13 janvier 2021.

\section{(c) (i) (9)}

Studi Francesi è distribuita con Licenza Creative Commons Attribuzione - Non commerciale - Non opere derivate 4.0 Internazionale. 


\title{
Barbara Bohac, La dernière mode de Mallarmé sous les feux du drame solaire
}

\author{
Ida Merello
}

\section{NOTIZIA}

BARBARA BOHAC, La dernière mode de Mallarmé sous les feux du drame solaire, «Romantisme», n. 132 (2-2006), pp. 129-140.

1 L'A. esamina gli otto numeri della «Dernière mode», scritti integralmente da Mallarmé, e, confortata dalla confidenza fatta a Verlaine dal poeta stesso, che riconosceva alla sua rivista il potere di farlo sognare, indaga, proseguendo nella direzione già indicata da Bertrand Marchal, le costellazioni dell'immaginario che si possono individuare in filigrana. Isola così quella che Mallarmé definisce «la tragédie de la nature», già collegata da Marchal al dramma solare, mostrando il rapporto antinomico tra lo splendore delle feste e l'assenza di sole della stagione invernale o della notte, e il valore sostitutivo delle toilettes femminili e delle decorazioni di interni. L'A. nota infine che il poeta è ben consapevole dell'insufficienza comprensiva del suo pubblico, per cui accompagna i suoi testi da una benevola ironia. 